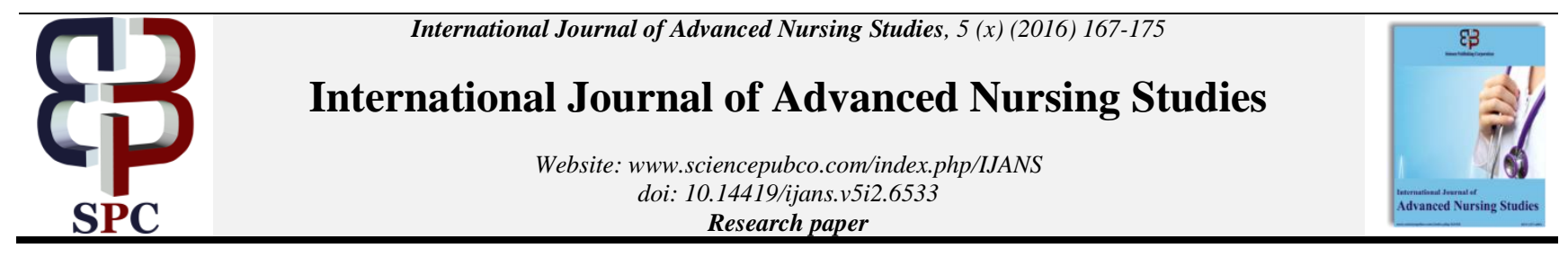

\title{
Impact of child labor in stone quarries on his health status in El- Minia city
}

\author{
Naglaa Saad Abd EL-Aty ${ }^{1}$, Nazek Ibrahim Abd EL-Ghany ${ }^{2}$, Farag Mohammed Moftah ${ }^{3}$, \\ Shokria Adly Labeeb ${ }^{4}$, Awatef Abdel-Razak Mohammed ${ }^{5} *$ \\ ${ }^{1}$ Assistant Lecturer of community Health Nursing, Faculty of Nursing, EL-Minia University \\ ${ }^{2}$ Prof.of Community Health Nursing, Faculty of Nursing, Alexandria University \\ ${ }^{3}$ Prof. of Public health, Faculty of Medicine, Assiut University \\ ${ }^{4}$ Prof. of Community Health Nursing, Faculty of Nursing, Assiut University. \\ ${ }^{5}$ Assistant Professor of community Health Nursing, Faculty of Nursing, EL-Minia University \\ *Corresponding author E-mail: awtif19672002@yahoo.com
}

\begin{abstract}
Background: Child labor today represents the largest single cause of child abuse across the global. Most of it takes place in economically less developed countries and much is hidden.

Objectives: The aims of this study were to found out the nature and impact of child labor in the stone quarries on his health status and assess the work hazards associated with these concern.

Methods Design: A descriptive comparative design was used .Setting: at stone quarries in El-Minia city and two Governmental schools (primary and preparatory).

Sample: Study consisted sample of two groups: two hundred working children (studied group) and three hundred school children as control group.

Tools: Three tools were developed and utilized. Socio-demographic characteristics, assessment sheet, and Observation check list.

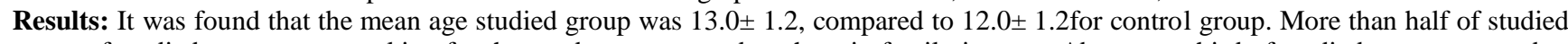
group of studied group were working for the need to money and to share in family income. About two third of studied group exposed to different types of injuries during work in quarry. There was statistical significant difference between studied and control group groups regarding body mass index physical assessment and bad habits. Also the results of this study explored that most of studied group exposed to all items of work hazards.

Conclusion: It can be concluded that almost all working children in stone quarries were facing much health complains and working hazards.

Recommendations: Quarries owners should provide all working children with appropriate protective measures and trained them on methods of protecting themselves from work hazards.
\end{abstract}

Keywords: Child; Health Status; Occupational Hazards; Stone Quarries; Students.

\section{Introduction}

Children are the future leaders of our society and valuable assets. It is the duty of individual in a society to see that the dreams and rights of child are fulfilled (Manitham 2005). Undoubtedly, children must grow properly, be strong and healthy, and be sufficiently intelligent and skilled to be useful members of their communities. So no one can deny their rights to grow and develop in a healthy and normal manner, to benefit from social security including adequate nutrition, adequate housing, recreation, and medical services, as well as to receive education and be protected against all forms of neglect, cruelty and exploitation (Mahmoud 2004).

Child labor works against human rights and investment in human development, against the provision of decent work and against the reduction of poverty (International programme on the elimination of child labor (IPEC) 2002). Also child labor is an important global issue associated with poverty, inadequate educational opportunities, gender inequality and a range of health risks (Reggero et al., 2007).
Child labor is defined as work that impairs the health, disrupts the education, and violates the rights of children. According to International Labor Organization (ILO), approximately 250 million children between the ages of five and fourteen work worldwide (.Prudom 2006). These children currently under conditions that are considered illegal, hazardous, or extremely exploitative. Underage children work all sorts of jobs around the world usually because they and their families are extremely poor. Child labor can be found in nearly every industry. Large numbers of children work in agriculture, fishing, manufacturing, mining, quarrying, and domestic services. Some children work in illicit activities like the drug trade and prostitution or other traumatic activities such as serving as soldiers (Child labor public education project, 2002).

The number one factor that contributes to child labor is parental poverty. Another major factor is the need for supplementary income. Other contributing factors include landlessness of the family, family size, the presence of handicapped parents, and the acquisition of skills at an early age for better employment prospects 
later in life and inadequate education. (Prudom 2006, U.S. Department of Labor 2006).

Child labor is used in stone quarrying operations in many countries in Africa, Asia, and Latin America. Those children work without adequate protective equipment, clothing, or training. They blasting rocks, breaking up stones with pick axes and carrying and loading stones into trucks (U.S. Department of Labor 2004). Such work has an adverse impact on the health and development of these children (Parker 1997). The work is both strenuous and dangerous. These Children are at risk for various lung and skin diseases, loss of eyesight, and physical deformities or loss of a limb. Children frequently do not attend school and child illiteracy is common (Sekar 1997 \& U.S. Department of Labor, (2004).

Three approaches to stop child la bor include: prevention, protection and rehabilitation. Regarding prevention, if child labor had a pusher, it ought to be poverty. Areas with high incidences of child labor always turn up to be poverty stricken. The issue becomes more complicated because parents ask their children to work Sometimes, children themselves volunteer out of poverty (Miller \& Kaufman 1998). Regarding Protection, children who are already working must be releases from child labor. In cases where releasing them is difficult or takes time, action should be made to make their life more tolerable and less hazardous. But children working in extremely hazardous work, in bonded labor, or in prostitution are the priority of rescue operation (Miller \& Kaufman 1998) Rehabilitation, after being rescued from child labor, the children after being rescued from child labor, and the children with their families must be given adequate services and facilities so that they will not revert to child labor. Projects in areas where families allow their children to go to work can also become a preventive measure against would-be victims of child labor (Miller \& Kaufman 1998)

Pilot projects of the International Labor Organization (ILO) have demonstrated that it is possible to eliminate child labor by helping quarrying communities organize cooperative or other productive units, improves the health, safety and productivity of adult workers and secure essential services such as schools, clean water and sanitation system (Somvia 2005)

The community health nurse plays an important role in stimulating the community awareness about the problem of child labor, to participate in its control and establish a national system of social security, health insurance, and work compensation to cover this sector of actually working children (Haggag 1995, Clark 1996, Stanhope \& Lancaster 2002).

In view of her expanded role the community health nurse can assume manly roles while serving in different community health agencies, namely ambulatory care settings, schools, work places and particularly at work (Stanhope M \& Lancaster 2000, Mahmoud 2004).

The community health nurse as health promoter in the areas of occupational and school health has to meet the preventive and primary health care needs of labored school children. Thus her preventive role can be provided according to three levels of prevention; primary, secondary and tertiary level of prevention (Hitchcock 1999, Niles \& Mcewen 2001, Edelman \& Mandle 2002, Alllender \& Spradley 2005.

This study aimed to assess the nature of child labor in the stone quarries, Identify the impact of child labor in the stone quarries on his health status, and Assess the work hazards associated with child labor in the quarries sector.

\section{Methodology}

\subsection{Design}

A descriptive comparative design was used to explore the nature of child and impact of child labor in the stone quarries on his health status as well as work hazards associated with child labor in the quarries sector.

\subsection{Setting}

The present study was carried out in two different settings: Stone quarries in El-Minia city and two Governmental schools (primary and preparatory) selected from the same previous setting. The total numbers of schools were 15 , seven primary and eight preparatory.

\subsection{Sample}

Study sample consisted of two groups: two hundred working children (studied group) and three hundred school children as control group (62 students from primary and 238 students from preparatory school).).

Both studied and control groups selected by using quota sample technique

Criteria for selected studied group:

- Child's age ranged from 6 to less than 15 years.

- Working on regular basis i.e. full time.

- Not attending school beside work

- Duration of working must be more than one year.

\subsection{Tools}

Three tools were developed and utilized be the researcher to collect data based on review of literature.

Toole I- Socio-demographic characteristics: It was used to assess child's personal and family profile such as age, birth order and level of education, parent's education, job, family income, and its source, number of siblings, housing condition.

Tool II- Assessment sheet: it was contains from the following:

A- Physical assessment; includes assessment of various systems as integumentary, digestive respiratory, cardio and musculoskeletal systems as well as assessment of eyes.

B- Assessment of nutritional stats: it was assessed body mass index and skin fold thickness.

C- Health habits and practices: such as smoking or drug or alcohol abuse that may affect child health were assessed.

Tool III- Observation check list: it was developed to observe each child during his actual work to identify the occupational hazards, industrial safety measures.

\subsection{Data collection procedure}

1) Before the conduction of the study, a written permission was obtained from the Dean of Nursing Faculty at El-Minia University, and then official letter was submitted from Faculty of Nursing to the Governor of El-Minia to obtain his approval to collect the study data from the selected quarries. Official letter was issued from El-Minia Governor and addressed to the manger of quarries' project to obtain his approval to collect the study data. After approval of manger of quarries' project had obtained the official letter was submitted to nongovernmental association called Kretas Egypt which addressed this letter to Wadi El-Nile association which was responsible about quarries workers and which was arranged the meeting schedule with working children in each selected quarry. Each organizer in Wadi El-Nile association sectors or branches in villages in which the selected quarries located was informed about the time of visit and the purpose of the study to obtain her approval and cooperation in the preparation the selected children.

2) Approval obtained from the manger of El-Minia chest hospital to carry out chest $\mathrm{x}$-ray for the study sample.

3) A written permission was obtained from the vice minister of education in El-Minia Governorate included his approval to visit the selected schools and then the approval was obtained from headmasters of each school to meet the selected children and collect the study data.

4) A pilot study was performed to evaluate, ensure the clarity, comprehensiveness and applicability of questionnaire. Also 
to estimate the approximate time required for each child. It was carried out on thirty children from the quarry of Zawiet Sultan. This sample was excluded from total sample, and then the necessary modifications was done and then according to the results of the pilot study the final form was developed and used in data collection.

5) Every child was interviewed individually by the researcher in selected in which the selected quarries located. Interviews were done in the morning or in the afternoon according to the status of work of child to obtain the necessary information, measure anthropometric measurements and performing the physical assessment for each child. A simple explanation of purpose of the study was done by the researcher to children to gain their cooperation. The length of time needed for interviewing of each child ranged from 3040 minutes. An average of ten children /day was interviewed during the visit. In each school explanation of the purpose of the research was done to the headmaster of each school to gain their cooperation. The researcher met the students according to their spare time (the classes were either with an absent teacher or had extra curriculum activities). The purpose of the study was explained in simple manner for students in each selected classes to gain students' cooperation.

\section{Results}

\subsection{Participant's demographics}

500 children participated in the study. (200 studies and 300 controls. Table (1) shows the demographic characteristic of the participants. It was found that the mean age by year of studied group was $13.0 \pm 1.2$ year compared to $12.0 \pm 1.2$ for control group. $16.5 \%$ and $40.0 \%$ respectively of studied group were in primary and preparatory education; while $43.5 \%$ of them were dropout the education, compared to $(20.7 \%$ and $79.3 \%$ respectively) of control group were in primary and preparatory education. Also the results revealed that about one quarter $(25.0 \%)$ of both studied and group their birth order was the first compared to $(30.8 \%)$ of control group.

Also table (1) shows that more than half (59.3\%) of studied group their fathers were illiterate, compared to less than half $(45.7 \%)$ of control group their fathers were illiterate. There was statistical significant difference between studied and control group regarding the father's education. As regard father's job this table shows that more than half of studied group their fathers were unskilled workers, with statistical significant difference between studied and control group regarding the father's job.

$(83.3 \%)$ of studied group their mothers were illiterate, while, compared to $(74.7 \%)$ of control group their mothers were illiterate Regarding to the family income it was found that $(70.5 \%)$ of studied group their family income was 130 pound and more. Also table (1) revealed that $(29.5 \%)$ of studied group their family contains six members, compared to $(30.7 \%)$ of control group

Moreover, more than two fifths (41.0\%) of studied group their houses consisting from four rooms, compared to one fifth (20.0\%) of control group croup, while $(13.5 \%)$ of studied group their houses were consisting from more than five rooms, compared to more than two fifths $(40.7 \%)$ of control group. Regarding to the type of house building it was found that more than three quarters $(77.0 \%)$ of studied group their houses were built from limestone bricks (white stone), compared to (70.3\%) of control group.

According to the reasons of child living with one parent it was observed that $(90.0 \%)$ of studied group were living with their mothers due to death of father, compared to $(46.7 \%)$ of control group, while $(10.0 \%)$ of studied group were living with their fathers due to death of mother, compared to $(53.3 \%)$ of control group.

Concerning to the socio-economic status it was found $(71.5 \%)$ of studied group had low social standard, compared to more than half
(52.0\%) of control group. There was statistical significant difference between studied and control group regarding the socioeconomic status $(\mathrm{p}=0.000)$.

Table 1: Participant Demographic Data

\begin{tabular}{|c|c|c|c|c|}
\hline \multirow{2}{*}{ Items } & \multicolumn{2}{|c|}{ Studied Group } & \multicolumn{2}{|c|}{ Control Group } \\
\hline & No. 200 & $\%$ & No. 300 & $\%$ \\
\hline \multicolumn{5}{|l|}{ Personal Data Of Studied Sample } \\
\hline \multicolumn{5}{|l|}{ Child's Age } \\
\hline $8-12$ years & 60 & 30.0 & 62 & 20.7 \\
\hline 13-14 Years & 140 & 70.0 & 238 & 79.3 \\
\hline Mean \pm Sd & $13.0 \pm 1.2$ & & $12.9 \pm 1.2$ & \\
\hline \multicolumn{5}{|l|}{ Child's Education } \\
\hline Primary & 33 & 16.5 & 62 & 20.7 \\
\hline Preparatory & 80 & 40.0 & 238 & 79.3 \\
\hline Drop Out Education & 87 & 43.5 & 0 & 0 \\
\hline \multicolumn{5}{|l|}{ Child's Birth Order } \\
\hline First & 50 & 25.0 & 92 & 30.8 \\
\hline Second & 43 & 21.5 & 61 & 20.3 \\
\hline Third & 34 & 17.0 & 49 & 16.3 \\
\hline Fourth & 31 & 15.5 & 49 & 16.3 \\
\hline Fifth & 14 & 7.0 & 22 & 7.3 \\
\hline Sixth And More & 28 & 14.0 & 27 & 9.0 \\
\hline \multicolumn{5}{|c|}{ Family Profile Of Studied Sample } \\
\hline \multicolumn{5}{|l|}{ Father's Education } \\
\hline Illiterate & 108 & 59.3 & 134 & 45.7 \\
\hline Read And Write (Elementary) & 33 & 18.1 & 67 & 22.9 \\
\hline Intermediate & 36 & 19.8 & 78 & 26.6 \\
\hline High Education (University) & 5 & 2.8 & 14 & 4.8 \\
\hline P-Value & 0.03 & & & \\
\hline \multicolumn{5}{|l|}{ Father's Job } \\
\hline Unskilled Worker & 101 & 55.5 & 108 & 36.9 \\
\hline Skilled Worker & 72 & 39.6 & 118 & 40.3 \\
\hline Business & 9 & 4.9 & 67 & 22.8 \\
\hline Total & $182 *$ & 100.0 & $293 * *$ & 100.0 \\
\hline P-Value & 0.000 & & & \\
\hline Mother's Education & & & & \\
\hline Illiterate & 165 & 83.4 & 218 & 74.7 \\
\hline Read And Write (Elementary) & 25 & 12.6 & 42 & 14.4 \\
\hline Intermediate & 5 & 2.5 & 29 & 9.9 \\
\hline High Education (University) & 3 & 1.5 & 3 & 1.0 \\
\hline Mother's Job & & & & \\
\hline Housewife & 174 & 87.9 & 270 & 92.5 \\
\hline Working (Unskilled) & 21 & 10.6 & 14 & 4.8 \\
\hline Employee & 3 & 1.5 & 8 & 2.7 \\
\hline Total & $198 *$ & 100.0 & $292 * *$ & 100.0 \\
\hline Continue Table (1) & & & & \\
\hline Family Income & & & & \\
\hline $90>110$ Pound & 2 & 1.0 & 1 & 0.3 \\
\hline $110>130$ Pound & 57 & 28.5 & 55 & 18.3 \\
\hline 130 And More & 141 & 70.5 & 244 & 81.4 \\
\hline Source Of Family Income & & & & \\
\hline Father & 53 & 26.5 & 217 & 72.4 \\
\hline Both Parents And Their Sons & 10 & 5.0 & 40 & 13.3 \\
\hline Father And His Sons & 110 & 55.0 & 29 & 9.6 \\
\hline Sons Only & 21 & 10.5 & 11 & 3.7 \\
\hline Mothers And Her Sons & 6 & 3.0 & 3 & 1.0 \\
\hline P-Value & 0.000 & & & \\
\hline Number Of Siblings & & & & \\
\hline One Sibling & 1 & 0.5 & 1 & 0.3 \\
\hline Two Siblings & 4 & 2.0 & 19 & 6.3 \\
\hline Three Siblings & 38 & 19.0 & 61 & 20.3 \\
\hline More Than Three Siblings & 175 & 78.5 & 219 & 73.0 \\
\hline Family Size & & & & \\
\hline Four Members & 18 & 9.0 & 22 & 7.3 \\
\hline Five Members & 47 & 23.5 & 68 & 22.7 \\
\hline Six Members & 59 & 29.5 & 92 & 30.7 \\
\hline Seven Members & 44 & 22.0 & 71 & 23.7 \\
\hline More Than Seven Members & 32 & 16.0 & 47 & 15.6 \\
\hline Housing Condition & & & & \\
\hline House Lord & 188 & 94.0 & 293 & 97.7 \\
\hline Flat Lord & 3 & 1.5 & 0 & 0 \\
\hline Rent The Flat & 7 & 3.5 & 7 & 2.3 \\
\hline Live With Some Relatives & 2 & 1.0 & 0 & 0 \\
\hline Numbers Of Rooms & & & & \\
\hline Three Rooms & 37 & 18.5 & 18 & 6.0 \\
\hline Four Rooms & 82 & 41.0 & 60 & 20.0 \\
\hline Five Rooms & 54 & 27.0 & 100 & 33.3 \\
\hline More Than Five Rooms & 27 & 13.5 & 122 & 40.7 \\
\hline
\end{tabular}




\begin{tabular}{lcccc}
\hline Type Of House Building & & & & \\
Red Bricks & 13 & 6.5 & 28 & 9.3 \\
Green Bricks & 33 & 16.5 & 61 & 20.3 \\
White Stone & 154 & 77.0 & 211 & 70.3 \\
With Whom The Child Living & & & & \\
With Both Parents & 180 & 90.0 & 285 & 95.0 \\
With His Father & 2 & 1.0 & 8 & 2.7 \\
With His Mother & 18 & 9.0 & 7 & 2.3 \\
Reasons Of Child Living With One Parent & & & \\
Father's Death & 18 & 90.0 & 7 & 46.7 \\
Mother's Death & 2 & 10.0 & 8 & 53.3 \\
\hline
\end{tabular}

\subsection{Nature of child labor in quarry}

Table (2) illustrates the nature of child labor in quarry it was found The mean duration of work was $26.1 \pm 9.18$. Regarding to the reasons of child working it was found that around half of were working for the need to money and to share in family income.

According to the nature of child work in quarry it was found that more than two fifth $(43.5 \%)$ of studied group were exchange the limestone bricks, followed by those who are modifying separator way and on stone crushers they constituted. Concerning the reasons for choosing this work, more than half $(52.5 \%)$ of them reported that they work in quarry because it's available and the only chance. However, the majority of children $(73.5 \%)$ were worked 10 hours per day and receiving one hour break during working hours. Also most of them were taking a weekly day off. Results also explore that more than half $(53.1 \%)$ of studied group hadn't any pre-placement training before starting the work in quarry. Also this table revealed that around two third $(69.0 \%)$ of studied group were not joining to another work before quarry work.

Table 2: Nature of Child Labor in Quarry

\begin{tabular}{|c|c|c|}
\hline Items & No 200 & $\%$ \\
\hline \multicolumn{3}{|l|}{ Duration Of Working } \\
\hline 18 Month & 66 & 33.0 \\
\hline 24 Month & 74 & 37.0 \\
\hline 36 Month & 47 & 23.5 \\
\hline 48 Month & 13 & 6.5 \\
\hline Mean \pm Sd & \multicolumn{2}{|c|}{$26.1 \pm 9.18$} \\
\hline \multicolumn{3}{|l|}{ Reasons Of Child Working } \\
\hline Need To Money & 58 & 29.0 \\
\hline School Failure & 5 & 2.5 \\
\hline Share In Family Income & 47 & 23.5 \\
\hline Like To Work & 31 & 15.5 \\
\hline The Job Is Better Than Education & 2 & 1.0 \\
\hline Parents' Wishes & 12 & 6.0 \\
\hline Educational Difficulties & 22 & 11.0 \\
\hline Working With Your Father & 5 & 2.5 \\
\hline Others & 18 & 9.0 \\
\hline \multicolumn{3}{|l|}{ Nature Of Work } \\
\hline Modifying Separator Way & 30 & 15.0 \\
\hline Exchange Limestone Bricks & 87 & 43.5 \\
\hline On Stone Crushers & 36 & 18.0 \\
\hline Loading Stone Into Trucks & 4 & 2.0 \\
\hline Modifying Cutter Way & 8 & 4.0 \\
\hline Powder Shaking & 5 & 2.5 \\
\hline More Than One Specialty & 30 & 15.0 \\
\hline \multicolumn{3}{|l|}{ Reasons For Choosing This Work } \\
\hline Likes To Work In Quarry & 27 & 13.5 \\
\hline Requiring No Qualification Or Special Skills & 12 & 6.0 \\
\hline It's The Available And Only Chance & 105 & 52.5 \\
\hline Having Knowledge About Quarry Work & 21 & 10.5 \\
\hline Others & 35 & 17.5 \\
\hline \multicolumn{3}{|l|}{ Hours Of Work } \\
\hline 8 Hours/Day & 53 & 26.5 \\
\hline 10 Hours/Day & 147 & 73.5 \\
\hline \multicolumn{3}{|l|}{ Rest Break/Day } \\
\hline Half An Hour & 26 & 13.0 \\
\hline An Hour & 174 & 87.0 \\
\hline \multicolumn{3}{|l|}{ Continue Table (2) } \\
\hline \multicolumn{3}{|l|}{ Taking Weekly Days Off } \\
\hline One Day & 195 & 97.5 \\
\hline Two Days & 5 & 2.5 \\
\hline \multicolumn{3}{|l|}{ Past Experience About Quarry's Machines } \\
\hline Yes & 4 & 2.0 \\
\hline No & 196 & 98.0 \\
\hline
\end{tabular}

Pre-Placement Training $($ No $=196)$

Yes

No

Length Of Training Period $(\mathrm{No}=92)$

Less Than One Week

One Week

Two Weeks

Child's Wage Per Week

90 Pound

100 Pound

120 Pound

150 Pound

180 Pound

Methods Of Spending Child's Wage

Spending All On Him Self

Spending On Him Self And His Family

Spending All On His Family

Joining To Another Work Before This Work

Yes

No

Type Of Previous Work $($ No $=62)$

Farming

Care Repair

Grocery

Carpenter Workshop

Building

Car Keeper

\begin{tabular}{cc}
92 & 46.9 \\
104 & 53.1 \\
& \\
53 & 57.6 \\
37 & 40.2 \\
2 & 2.2 \\
& \\
15 & 7.5 \\
12 & 6.0 \\
62 & 31.0 \\
80 & 40.0 \\
31 & 15.5 \\
& \\
46 & 23.0 \\
138 & 69.0 \\
16 & 8.0 \\
& \\
62 & 31.0 \\
138 & 69.0 \\
& \\
39 & 62.9 \\
1 & 1.6 \\
5 & 8.1 \\
6 & 9.7 \\
9 & 14.5 \\
2 & 3.2 \\
\hline
\end{tabular}

\subsection{Injury resulting from working in quarry}

Table (3) clears the distribution of studied group according to the injury resulting from working in quarry it was found that less than two third $(64.5 \%)$ of studied group exposed to injury during work in quarry. $(60.5 \%)$ their injuries were resulting from falling of heavy limestone and (10.8\%) of them their injuries were resulting from electrical cause, while (28.7) of them their injuries resulting from using unsafe machines. Moreover, $(44.2 \%)$ exposed to injury in their toes and legs. Regarding to the effect of injury it was found that more than three quarters $(75.2 \%)$ of them who exposed to injury, these injuries needed hospital admission.

Table 3: Injury Resulting from Working in Quarry

\begin{tabular}{|c|c|c|}
\hline ITEMS & $\mathrm{NO}=200$ & $\%$ \\
\hline \multicolumn{3}{|l|}{ Exposure to injury } \\
\hline Exposed & 129 & 64.5 \\
\hline Not exposed & 71 & 35.5 \\
\hline \multicolumn{3}{|l|}{ Causes of injury } \\
\hline Falling heavy stone & 78 & 60.5 \\
\hline Electrical cause & 14 & 10.8 \\
\hline Using unsafe machines & 37 & 28.7 \\
\hline \multicolumn{3}{|l|}{ Site of injury } \\
\hline Fingers and hand & 48 & 37.2 \\
\hline Head & 3 & 2.3 \\
\hline Toes of foot and legs & 57 & 44.2 \\
\hline More than one site & 21 & 16.3 \\
\hline \multicolumn{3}{|l|}{ Effect of injury } \\
\hline Hospital admission & 97 & 75.2 \\
\hline Permanent disability & 21 & 16.3 \\
\hline Lost part from body & 11 & 8.5 \\
\hline
\end{tabular}

\subsection{Physical assessment}

Table (4) shows the distribution of studied sample according to the physical assessment it was found that There was statistical significant between study and control group for all items of physical assessment with p- value 0.000 
Table 4: Distribution of Studied Sample According to the Physical Assessment

\begin{tabular}{|c|c|c|c|c|}
\hline \multirow{2}{*}{ Items } & \multicolumn{2}{|c|}{ Studied Group } & \multicolumn{2}{|c|}{ Control Group } \\
\hline & No. 200 & $\%$ & No. 300 & $\%$ \\
\hline \multicolumn{5}{|l|}{$\begin{array}{l}\text { Integumentory System } \\
* \text { Skin }\end{array}$} \\
\hline Normal & 1 & 0.5 & 197 & 65.6 \\
\hline Itching & 9 & 4.5 & 6 & 2.0 \\
\hline Dry Skin & 29 & 14.5 & 14 & 4.7 \\
\hline Cracked Skin & 4 & 2.0 & 2 & 0.7 \\
\hline Previous Scar & 36 & 18.0 & 13 & 4.3 \\
\hline Laceration & 9 & 4.5 & 9 & 3.0 \\
\hline Pallor Skin & 9 & 4.5 & 38 & 12.7 \\
\hline $\begin{array}{l}\text { More Than One } \\
* \text { Hair }\end{array}$ & 103 & 51.5 & 39 & 13.0 \\
\hline Normal & 161 & 80.5 & 284 & 94.7 \\
\hline Hair Falling & 20 & 10.0 & 6 & 2.0 \\
\hline $\begin{array}{l}\text { Others } \\
* \text { Nails }\end{array}$ & 19 & 9.5 & 10 & 3.3 \\
\hline Normal & 124 & 62.0 & 289 & 96.3 \\
\hline $\begin{array}{l}\text { Platynchia } \\
\text { *Teeth }\end{array}$ & 76 & 38.0 & 11 & 3.7 \\
\hline Normal & 87 & 43.5 & 198 & 66.0 \\
\hline Mottled Teeth & 25 & 12.5 & 38 & 12.7 \\
\hline Decayed Teeth & 63 & 31.5 & 51 & 17.0 \\
\hline Missed Teeth & 9 & 4.5 & 1 & 0.3 \\
\hline $\begin{array}{l}\text { More Than One } \\
* \text { Gum }\end{array}$ & 16 & 8.0 & 12 & 4.0 \\
\hline Normal & 181 & 90.5 & 298 & 99.3 \\
\hline $\begin{array}{l}\text { Spongy, Bleeding, Spots } \\
* \text { Tongue }\end{array}$ & 19 & 9.5 & 2 & 0.7 \\
\hline Normal & 152 & 76.0 & 291 & 97.0 \\
\hline Fissured Tongue & 48 & 24.0 & 9 & 3.0 \\
\hline Digestive System & & & & \\
\hline Normal & 105 & 52.5 & 251 & 83.7 \\
\hline Vomiting & 10 & 5.0 & 7 & 2.3 \\
\hline Anorexia & 18 & 9.0 & 3 & 1.0 \\
\hline Diarrhea & 12 & 6.0 & 10 & 3.3 \\
\hline Colic & 39 & 19.5 & 26 & 8.7 \\
\hline More Than One & 16 & 16.0 & 3 & 1.0 \\
\hline
\end{tabular}

\begin{tabular}{|c|c|c|c|c|}
\hline \multicolumn{5}{|l|}{ Respiratory System } \\
\hline \multicolumn{5}{|l|}{$*$ Chest } \\
\hline Normal & 12 & 6.0 & 223 & 74.3 \\
\hline Cough & 35 & 17.5 & 33 & 11.0 \\
\hline Cough With Sputum & 71 & 35.5 & 34 & 11.3 \\
\hline Dyspnea & 12 & 6.0 & 0 & 0 \\
\hline Chest Pain & 6 & 3.0 & 1 & 0.3 \\
\hline Asthma & 6 & 3.0 & 0 & 0 \\
\hline \multicolumn{5}{|l|}{$*$ Nose } \\
\hline Normal & 43 & 21.5 & 221 & 73.7 \\
\hline Nasal Obstruction & 51 & 25.5 & 33 & 11.0 \\
\hline Continuous Influenza & 4 & 2.0 & 17 & 5.7 \\
\hline Epistaxis & 13 & 6.5 & 7 & 2.3 \\
\hline Nasal Breathing & 5 & 2.5 & 1 & 0.3 \\
\hline Continuous Catarrhal & 31 & 15.5 & 0 & 0 \\
\hline Wheezing & 20 & 10.0 & 0 & 0 \\
\hline Nasal Discharge & 24 & 12.0 & 8 & 2.7 \\
\hline More Than One & 9 & 4.5 & 13 & 4.3 \\
\hline \multicolumn{5}{|l|}{ Musculoskeletal System } \\
\hline Normal & 12 & 6.0 & 248 & 82.7 \\
\hline Backache & 77 & 38.5 & 22 & 7.3 \\
\hline Muscle Twitching & 48 & 24.0 & 21 & 7.0 \\
\hline Sprains & 3 & 1.5 & 2 & 0.7 \\
\hline Fatigue & 15 & 7.5 & 3 & 1.0 \\
\hline More Than One & 45 & 22.5 & 4 & 1.3 \\
\hline \multicolumn{5}{|l|}{ Cardiovascular System } \\
\hline Normal & 158 & 79.0 & 282 & 94.0 \\
\hline Slow Heart Rate & 5 & 2.5 & 2 & 0.7 \\
\hline Rapid Heart Rate & 32 & 16.0 & 13 & 4.3 \\
\hline Weak Pulse & 5 & 2.5 & 3 & 1.0 \\
\hline \multicolumn{5}{|l|}{ Eye } \\
\hline Normal & 85 & 42.5 & 241 & 80.3 \\
\hline Blurred Vision & 19 & 9.5 & 17 & 5.7 \\
\hline Excessive Tearing & 24 & 12.0 & 10 & 3.3 \\
\hline Redness & 52 & 26.0 & 15 & 5.0 \\
\hline Impaired Sight & 5 & 2.5 & 9 & 3.0 \\
\hline More Than One & 15 & 7.5 & 8 & 2.7 \\
\hline
\end{tabular}

\subsection{Anthropometric measures}

Table (5) shows the distribution of studied sample according to the body mass index it was found that There was statistical significant difference between studied and control group groups regarding body mass index $(\mathrm{p}=0.01)$.

Table 5: Distribution of Studied Sample According to Their Anthropometric Measures

\begin{tabular}{|c|c|c|c|c|}
\hline \multirow{2}{*}{ Items } & \multicolumn{2}{|c|}{ Studied Group } & \multicolumn{2}{|c|}{ Control Group } \\
\hline & No. 200 & $\%$ & No. 300 & $\%$ \\
\hline \multicolumn{5}{|l|}{ Body Mass Index } \\
\hline Under Weight & 19 & 9.5 & 14 & 4.7 \\
\hline Normal & 150 & 75.0 & 252 & 84.0 \\
\hline At Risk & 17 & 8.5 & 24 & 8.0 \\
\hline Over Weight & 14 & 7.0 & 10 & 3.3 \\
\hline P-Value & \multicolumn{4}{|l|}{0.01} \\
\hline Items & \multicolumn{2}{|l|}{$\begin{array}{l}\text { Studied } \\
\text { Group } \\
\text { Mean }+ \text { Sd }\end{array}$} & Control Group & T-Test \\
\hline Skin Fold Thickness & $\begin{array}{l}\text { Mean } \pm \text { Sd } \\
.82 \pm .39\end{array}$ & & $\begin{array}{l}\text { Mean } \pm \text { Sd } \\
.95 \pm .54\end{array}$ & 0.004 \\
\hline $\begin{array}{l}\text { Mid Arm Circum- } \\
\text { ference }\end{array}$ & $20.3 \pm 2.3$ & & $19.5 \pm 2.9$ & 0.006 \\
\hline
\end{tabular}

\subsection{Bad health habits}

Table (6) shows the distribution of studied sample according to the bad health habits it was found that (31.5\%) of studied group were smokers, compared to (5.7\%) of control group. There was statistical significant difference between studied and control group groups regarding the practice of smoking habit $(\mathrm{p}=0.000)$.

According to the addiction it was found that $(11.0 \%)$ of studied group were addicted, while no one of control group were addicted. Moreover, more than half $(54.5 \%)$ of studied group were drug abused and $(45.5 \%)$ of them used others things as plants which called tatora.

Table 6: Comparison between Studied and Control Group According to Their Bad Health Habits

\begin{tabular}{|c|c|c|c|c|}
\hline \multirow{2}{*}{ Items } & \multicolumn{2}{|c|}{ Studied Group } & \multicolumn{2}{|c|}{ Control Group } \\
\hline & No. $=200$ & $\%$ & No. $=300$ & $\%$ \\
\hline \multicolumn{5}{|l|}{ Smoking } \\
\hline Smoker & 63 & 31.5 & 17 & 5.7 \\
\hline Non Smoker & 137 & 68.5 & 283 & 94.3 \\
\hline P-Value & 0.000 & & & \\
\hline \multicolumn{5}{|l|}{ Duration Of Smoking } \\
\hline One Year & 18 & 28.5 & 7 & 41.2 \\
\hline Two Years & 34 & 54.0 & 10 & 58.8 \\
\hline Three Years And More & 11 & 17.5 & 0 & 0.00 \\
\hline \multicolumn{5}{|l|}{ Type Of Smoking } \\
\hline Cigarette & 60 & 95.2 & 17 & 100.0 \\
\hline Shesha & 3 & 4.8 & 0 & 0.00 \\
\hline \multicolumn{5}{|c|}{ Number Of Cigarette Per Day } \\
\hline Four Cigarettes & 8 & 10.0 & 3 & 17.6 \\
\hline Eight Cigarettes & 14 & 23.3 & 4 & 23.5 \\
\hline Ten Cigarettes & 14 & 23.3 & 8 & 47.1 \\
\hline Fifteen Cigarettes & 21 & 35.0 & 2 & 11.8 \\
\hline Twenty Cigarette & 5 & 8.4 & 0 & 0.00 \\
\hline \multicolumn{5}{|l|}{ Addiction } \\
\hline Addicted & 22 & 11.0 & 0 & 0.00 \\
\hline Not Addicted & 178 & 89.0 & 0 & 0.00 \\
\hline \multicolumn{5}{|l|}{ Type Of Addiction } \\
\hline Drug Abuse & 12 & 54.5 & 0 & 0.00 \\
\hline Others & 10 & 45.5 & 0 & 0.00 \\
\hline
\end{tabular}

\subsection{Work hazards}

Table (7) shows the distribution of studied group according to the exposure to occupational hazards and their work environment and the presence of personal protection equipment. These results explored that most of studied group exposed to all items of work hazards and these are a serious indicators, that all children who are working at quarries setting may be exposed to many injuries or diseases. 
Table 7: Distribution of Studied Group According to Their Exposure to Work Hazards

\begin{tabular}{|c|c|c|}
\hline Items & No 200 & $\%$ \\
\hline \multicolumn{3}{|l|}{ Physical Hazards } \\
\hline Bad Odors & 200 & 100.0 \\
\hline Poor Lighting & 178 & 89.0 \\
\hline Poor Ventilation & 200 & 100.0 \\
\hline Excessive Heat & 200 & 100.0 \\
\hline Excessive Cold & 200 & 100.0 \\
\hline \multicolumn{3}{|l|}{ Mechanical Hazards } \\
\hline Use Of Sharp Tools & 196 & 98.0 \\
\hline Use Of Unsafe Machines & 196 & 98.0 \\
\hline \multicolumn{3}{|l|}{ Chemical Hazards } \\
\hline Use Of Chemicals & 200 & 100.0 \\
\hline Dust & 200 & 100.0 \\
\hline \multicolumn{3}{|l|}{ Psychosocial Hazards } \\
\hline Emotional Strain & 168 & 84.0 \\
\hline Stress & 195 & 97.5 \\
\hline Interpersonal Problems & 163 & 81.5 \\
\hline \multicolumn{3}{|l|}{ Cleanliness Of Workplace } \\
\hline Inadequate & 200 & 100.0 \\
\hline \multicolumn{3}{|c|}{ Presence Of Tap Water For Drinking } \\
\hline Not Present & 200 & 100.0 \\
\hline \multicolumn{3}{|l|}{ Presence Of Toilet Facilities } \\
\hline Not Present & 200 & 100.0 \\
\hline \multicolumn{3}{|c|}{ Presence Of Place For Eating And Rest } \\
\hline Not Present & 200 & 100.0 \\
\hline \multicolumn{3}{|l|}{ Hand Protection } \\
\hline Not Present & 200 & 100.0 \\
\hline \multicolumn{3}{|l|}{ Foot Protection } \\
\hline Not Present & 200 & 100.0 \\
\hline \multicolumn{3}{|l|}{ Head Protection } \\
\hline Not Present & 114 & 57.0 \\
\hline Irrelevant & 86 & 43.0 \\
\hline \multicolumn{3}{|l|}{ Special Cloths } \\
\hline Not Present & 200 & 100.0 \\
\hline \multicolumn{3}{|l|}{ Eye Protection } \\
\hline Not Present & 110 & 55.0 \\
\hline & 90 & 45.0 \\
\hline \multicolumn{3}{|l|}{ Ear Protection } \\
\hline Not Present & 200 & 100.0 \\
\hline \multicolumn{3}{|c|}{ Child's Using Of Personal Protective Equipment } \\
\hline No & 102 & 51.0 \\
\hline Not Always & 98 & 49.0 \\
\hline \multicolumn{3}{|c|}{ Special Place For Keeping Personal Protective Equipment } \\
\hline Not Present & 200 & 100.0 \\
\hline
\end{tabular}

\section{Discussion}

Child labor constitutes a major challenge everywhere, whether in developed or developing world. Working children have a high rate of accidental injury on the job. Work keeps children from normal childhood activities and often from school (Ibrahim et al., 1999) Also child labor is recognized as global health problem and it remains one of the most provocative and controversial challenges facing the world at the beginning of the 21 st century. Child labor in stone quarries has an adverse impact on the health and development of working children (Reggero et al., 2007). Child labor in quarrying is in virtually all cases, a worst form of child labor because of the extent and severity of the hazards and the risks of death, injury and diseases (International labor organization 2005). Therefore, the present study was initiated to identify the impact of child labor in stone quarries on his health status in El-Minia city.

\subsection{Personal data of the studied sample}

The Egyptian child law (1996) and the national law in many countries prohibit children from working before the age of fourteen; the present study revealed that all of the studied group were less than 15 years old. This finding agreed with (Haggag in 1995 , Mahmoud 2004, the national survey of Egyptian adolescents in 1999). As regard child's education, the results of this study shows that more than two fifths of the studied groups were dropout from education. This may be attributed to the exposure of working children to injury, long duration of working hours and hard work of quarrying work which prevent these children from going to school and hence miss the class hours, also working children always complaints from fatigue and headache which affect the child concentration. The present study was agreement with (Yassi 2001\& Mahmoud 2004).

On the other hand the present study reported that about quarter of the studied group was the first and second child in the family. This may be explained as the norms of our society as the eldest child must be share in family income with his parents. The present study is in disagreement with (Haggag1995) who reported that most of the working children were the second or third child in the family.

\subsection{Family profile of the studied sample}

Regarding to their father's education the present study indicated that more than half of the studied group their fathers' were illiterate. This may be attributed to early employment of working children resulting from father's ignorance about the importance of education. This result go in line with (Haggag 1995) and study carried out in Lebanon by (. Nuwayhid et al; 2005).

Also more than half of the studied group their father's jobs were unskilled workers especially in quarrying sector. This may be explained by the norms of our society as some families have a tradition of their children must following their parents' footsteps (i e those fathers have concept that their children must take the same job of them). These results go in line with study carried out in Alexandria by (Mahmoud 2004)

On other hand the present study revealed that more than half of the studied group their family source of income was the father and his sons. This can be attributed to child labor is considered as a mean to improve family economic status. Also the present study showed that some of the studied group comes from large families. This may be attributed to the economic burden which exists on parents of large family number which lead to employment of their children. The same finding was reported by other studies (Mitra 1993, Haggag 1995, Leske \& Ripa 1996).

\subsection{Nature of child labor in quarry}

Concerning to duration of working, the present study recorded that about half of the studied group had been working between 24 to 36 months. These results go in line with (Nuwayhid et al 2005). According to the reasons of starting the work among studied group it was found that the main common causes of work among studied group were need to money, to share in family income and due to educational difficulties. This may be explained as those children come from very low social standard families. This finding comes in the same line with (Haggag 1995, national survey of Egyptian adolescents 1999, Assaad 2001, Hawamedeh et al; 2001, Mahmoud 2004

The present study indicated that more than two fifth of the studied group were exchange limestone bricks, followed by those who are modifying separator way and those who work on stone crushers. Also the present study showed that the most common reasons of choice this job were it is the only available chance, or likes to work in stone quarry, or for other reasons such as wages in the quarries are more than any job, or there is no other workshops in their villages and or to be as other children who work in the quarry. This finding is agreed with (Haggag 1995).

The labor low sets a maximum number of working hours per day as six hours for young person's their age ranged from (15-18 years) and the working hours should interrupted with one or more meal breaks for every four consecutive working hours a rest break not less than one hour should follow. However, the situation in this present study was different, where less than three quarters $(73.5 \%)$ of the studied group were working up to ten hours daily and $(13.0 \%)$ of them were working up to eight hours daily. Similar results were reported by (Haggag 1995). Moreover, the vast majority of the studied group were taking one day off weekly. This finding is in contrast to the study of (Haggag 1995). 
Pre-placement training or orientation is very important to help workers to gain knowledge and develop the skills necessary to perform the job efficiently and it throws light on the hazards involved in the job and measures to protect themselves. The present study indicated that more than half of the studied group hadn't received any pre-placement training or orientation before starting the work in the quarry. The same finding was reported by other study (Haggag 1995. In spite of the dangers, however, many children choose quarry work over other jobs simply because its pays better so that the present study recorded that two fifths of the studied group were receiving 150 Egyptian pounds per week and less than one third of them were receiving 120 Egyptian pounds pre week. This finding comes in the same line with (daily star Egypt staff 2006) and in contrast to study of (Haggag 1995), this is may be due to the different of study setting of this study.

As regard the methods of spending child's wage, the present study clears that more than two third of the studied group were spending their wages on themselves and on their families. Similar results were reported by (Nuwayhid et al; 2005). Also the present study showed that more than two third of the studied group were not jointed to another work before stone quarry work. This is may be due to quarrying sector is the only and available job and it provides wages more than any other job.

\subsection{Injury resulting from working in quarry}

The present study revealed that less than two third of the studied group was exposed to work injury during their work in the form of cuts, lacerations, abrasions, falling and fractures. This resulted from falling heavy limestone bricks $(60.5 \%)$, using unsafe machine $(28.7 \%)$ and electricity $(10.8 \%)$. Moreover, more than one third $(37.2 \%)$ of these injuries were in fingers and hand and more than two fifth $(44.2 \%)$ of these injuries were in toes of foot and legs. This is may be due to falling of limestone bricks on the legs and hands.

Concerning to the effect of work injury, the present study recorded that more than three quarters of work injuries were required hospitalization, and $(16.3 \%)$ of work injuries causing permanent disability such as amputation of a finger or toe, partial loss of vision or impaired hand movement. This is may be due to lack of preplacement training, lack of experience, lack of attention span of young children, unavailability of protective equipment and incompatibility of the physical strength and measurements of the child with the used tools and performed tasks. The same findings were reported by other studies (International programme on the elimination of child labor (IPEC), 2002, Daily star Egypt staff, 2006).

The present study revealed that most of the studied group were exposed to injury among their different types of work. The most common nature of work in which the children were exposed to injury was modifying separator way, exchange limestone bricks, on stone sorters and who work more than one nature of work. This is may be attributed to quarrying work is dangerous and hazardous in all natures of its work. In relation to the relation between nature of work and causes of injury the present study showed the most common causes of injury among studied group who exchange limestone bricks were falling heavy limestone and electrical cause, also the using of unsafe machines and electrical cause were the most common causes of injury among studied group who modifying separator way.

\subsection{Nutritional status of study sample}

The present study indicated that three quarters $(75.0 \%)$ of the studied group had normal weight, $(9.5 \%)$ of them were under weight and $(7.0 \%)$ of them were overweight, compared to $(84.0 \%$, $4.7 \%$ and $3.3 \%$ respectively) of control group. This is due to a consequence of poor and imbalanced diet because the majority of the studied group depend on carbohydrates as the main source of food intake. This result go in line with (Haggag 1995).

\subsection{Effect of child labor in stone quarries on his physi- cal status}

The present study revealed that most of the studied group reported one or more of physical complaints which affecting the different body system

Integumentary complaints: which include skin, hair, nails, teeth, gum and tongue problems, which were reported in high percentage among studied group than control group. Skin disorders were the most frequently reported category of occupational diseases in quarrying sector. It was manifested in the form of dry skin $(14.5 \%)$, pervious scars $(18.0 \%)$, lacerations $(4.5 \%)$, and more than one complaints $(51.5 \%)$, compared to $4.7 \%, 4.3 \%, 3.0 \%$ and $13.0 \%$ respectively) of control group. This is may be due to exposure to chemicals, sunlight, using unsafe machines or falling heavy limestone bricks, while among control group it was occurred during playing. The same finding was reported by other study (Graitcer \& Lerer 2000).

Concerning to the nails disorders, it was found that more than one third $(38.0 \%)$ of the studied group were had platynchia nails, compared to $(3.7 \%)$ of control group. Teeth disorders in the form of decayed teeth were higher among studied group than control group. This finding may be attributed to studied group were consumed large amount of carbohydrates in the form of sweet and due to bad oral hygiene among them. These results go in line with Mahmoud (2004, Haggag 1995).

Digestive complaints; the most common digestive problems among studied group were abdominal colic, anorexia and diarrhea. These may be due to lack of personal hygiene and or irregular time of meals. The same finding was reported by other studies (Haggag 1995, .Human Rights Watch, 2002, Mahmoud 2004).

Respiratory complaints; the most common respiratory complaints among studied group were cough with sputum, cough, dyspnea, nasal obstruction, epistaxis, continuous catarrhal and nasal discharge. These complain were more prevalent among studied group than control group. This may be due to occupational exposure of the studied group to various types of dust, as well as high temperature and humidity and due to large number of the studied group were smokers. The same respiratory manifestations were stated by other studies (. Mahmoud 1995, Nuwayhid et al, 2005).

Musculoskeletal complaints; such as backache, muscle twitching and fatigue were also most prevalent among the studied group than the control group. This is resulting from lifting heavy limestone bricks, or from nature of work assumed by those children because some natures of work requiring long standing for long periods of times or squatting position. This finding is in agreement with other studies (Mahmoud 2004,Nuwayhid et al,.2005).

According to the cardiovascular complaints, the present study reported that rapid heart rate was most common among studied group than control. This may be attributed to functional disorders aggravated by work, stress and effort. These findings go in line with other studies (Mahmoud 2004, Nuwayhid et al,.2005).

Eye complaints were also more reported by studied group than control group. The most frequently eye complaints were redness of eyes, tearing eyes and blurred vision. Redness of eyes and blurring of vision may be due to defect in visual acuity, and chemical exposure to dust and excessive hot weather, while blurring of vision among control group has other reasons as improper lighting and defect in visual acuity particularly requiring eye glasses. These results go in line with other studies (Quandt et al, 2001, Mahmoud 2004).

\subsection{Health habits and practices}

early child labor can lead to exposure of working children to undesirable role models and to adverse habits such as smoking, drug abuse and drinking this finding supported by present study which indicated that less than one third $(31.5 \%)$ of the studied group were smokers, compared to $(5.5 \%)$ of control group. Moreover, more than half of the studied group who smokers were starting the smoking for two years. This may be attributed to quarry work 
provides working children with a sense of independence and an opportunity to spend long hours outside the home, also quarry work encourage young children to imitate their adult peers in such habits and they have the money to purchase the smoking to prove their manhood. This result is in agreement with other studies (. Haggag 1995, Nuwayhid et al 2005).

In addition, (11.0\%) of the studied group were addicted and more than half of them were dependent on drugs. They were mainly dependent on medicaments, alcohol and other popular plants such as tatora. This is denotes that the work expose working children to adverse habits such as drug abuse this is may be due to psychological and social factors such as imitation, encouragement by older work mates and the work help those children to have the money to purchase these things, this finding go in line with (Haggag 1995 Nuwayhid et al; 2005).

\subsection{Work hazards associated with child labor in stone quarries}

Working children in stone quarries are exposed to many hazards that impaired their safety and health. The present study reported that all studied group were exposed to physical hazards such as poor ventilation, bad odors, excessive heat, excessive cold and poor lighting. Also the vast majority of the studied group were exposed to mechanical hazards. This is due to using of sharp tools and the using of unsafe machines. Moreover, all studied group were exposed to chemical hazards such as dusts. Concerning to psychological hazards, the present study revealed that most of the studied group were exposed to psychological hazards such as emotional strain, stress and interpersonal problems. These results are in agreement with other studies (Haggag 1995, Mahmoud 2004).

The present study reported that environmental sanitation was poor in all selected stone quarries because there was inadequate cleanliness, absence of toilet facilities, absence of tap water for drinking and there wasn't special place for eating and rest. Also the present study recorded that personal protective equipment were available in few quarries (table 28 ) but it was incomplete and used by a few percent of working children and wasn't stored well. These results go in the same line with (Haggag 1995, Mahmoud 2004)

Regarding the health services which offered in the quarries, the present study found that all studied group not subjected to preemployment or periodic medical examination which useful in early detection, diagnosis and proper treatment of occupational problems which facing working children. Also the present study reported that all studied group weren't insured medically such as control group.

Health insurance which gives young workers the right to be treated in case of disease as well as to be compensated in case of accident like adult workers was not available in all selected stone quarries. In addition, first aid equipment was present in very few quarries but it was incomplete and there is no special and safe place in the quarries for keeping them. Finally all selected stone quarries aren't protect the working children from occupational hazards and not provide personal protective equipment as well as not provide periodic examination or health insurance for working children.

\section{Conclusion}

It can be concluded that almost all working children in stone quarries were facing many health complains such as dry skin, pervious scars, petechial nails, decayed teeth, cough with sputum, cough, dyspnea, nasal obstruction, epistaxis, backache, muscle twitching, fatigue, redness of eyes, tearing eyes, blurred vision. They usually use unsafe machines and carry heavy limestone bricks which led to cuts, lacerations, falling and fractures.

Working children in stone quarries are exposed to many hazards that impaired their safety and health. Environmental sanitation was poor in all selected stone quarries because there was inade- quate cleanliness, absence of toilet facilities, absence of tap. All selected stone quarries aren't protecting the working children from occupational hazards and not provide personal protective equipment as well as not provide periodic examination or health insurance for working children.

We can recommend that. Provide non-formal education to the working children and place them in a formal education program, provide the parents of children with functional education and opportunities for initiating income generating activities. Working children, their families and employers should receive full information about occupational illnesses and injuries related to quarry work on a regular basis .Also Quarries owners should provide all working children with appropriate protective measures and trained them on methods of protecting themselves from work hazards. In addition insure implementation of the child labor law and its convention for protections of working children in quarrying sector.

\section{Acknowledgements}

The authors received no financial or other support for the research reported in this manuscript.

\section{References}

[1] Manitham S, (2005).Promoting human rights, protecting environment, India. www. Tramilinforevice.com/ manitham/

[2] Mahmoud N, (2004). The effect of agricultural work on the status of preparatory school children. Decree of Master Thesis. Faculty of Nursing, Alexandria University.

[3] International programme on the elimination of child labor (IPEC) and statistical information and monitoring programme on child labor (SIMPOC), (2002). Every child counts-new estimate on child labor. Geneva: international labor office.

[4] Reggero P, Mangriatrra V, Bustreo F \& Rosati F, (2007). The health impact of child labor in developing countries. American journal of public health. Washington: Feb., vol. 97, Iss.2; pg.271.

[5] Prudom V, (2006).General information and background about child labor.

[6] Child labor public education project, (2002). What is child labor. Http// www.continuetolearn.uiowa.edu/laborctr/childlabor /index.html.

[7] U.S. Department of Labor, (2006).Advancing the campaign against child labor efforts at the country level. Washington: bureau of international labor affairs. www.dol.gov/ilab.

[8] U.S. Department of Labor, (2004). Chapter II: assessment of the problem. Washington: bureau of international labor affairs. www.dol.gov/ilab.

[9] Parker D, (1997). Health effects of child labor. The lancet. London: Nov, 8, vol.350, Iss.9088; pg.1395.

[10] Sekar A, (1997). A study of granite export and bondage of stone cutters in Tamilnadu (India: the association of the rural poor, n.d.

[11] Miller M E \& Kaufman J D, (1998). Occupational injuries among adolescents in Washington State. American journal of industrial medicine; 34 (2): 12035. http://dx.doi.org/10.1002/(SICI)10970274(199808)34:2<121::AID-AJIM4>3.0.CO;2-\#.

[12] Somvia J, (2005). Eliminating child labor: Amoral cause and a development challenge. E journal USA.

[13] Haggag M, (1995). The impact of child's labor on his health status in Alexandria. Decree of Doctor Thesis. Faculty of Nursing, Alexandria University.

[14] Stanhope M \& Lancaster J, (2002). Foundations of community health nursing: community oriented practice. Mosby, Philadelphia: pp.355-529.

[15] Clark M J, (1996). Nursing in the community, (2nd ed). Appleton and Lange, A Simon and Schuster Company, United States: pp.575600 .

[16] Stanhope M \& Lancaster J, (2000). Community and public health nursing, (5th ed). Mosby, New York: pp.527-41.

[17] Alllender J A \& Spradley B W, (2005). Community health nursing: concepts and practice, "(6th ed). Lippincott, Philadelphia: pp.581597

[18] Hitchcock J E, Schubert P E \& Thomas S A, (1999).Community health nursing: caring in action. An international Thomson publishing company, London: pp. 
[19] Niles MA \& Mcewen M, (2001).Community health nursing: promoting the health of population, (3rd ed). W.B. Saunders Company, Philadelphia: pp.738-740.

[20] Edelman C L \& Mandle CL, (2002).Health promotion throughout the life span, (5th ed). Mosby, New York.

[21] Ibrahim B, Sallam S, El-Tawila S, El-Gibaly O and El-Sahn F, (1999). Transitions to adulthood: A national Survey of Egyptian adolescents. Giza, Egypt: the population council regional office for West Asia and North Africa.

[22] International labor organization, (2005). International Programme on the Elimination of Child labor (IPEC): eliminating child labor in mining and quarrying, background document; World Day against Child Labor, 12 June 2005. International Labor Office, Geneva.

[23] Yassi A, Kjelstrom T, Kok T D and Guidotti T, (2001). Basic environmental health. New York: WHO. Oxford University. Press. http://dx.doi.org/10.1093/acprof:oso/9780195135589.001.0001.

[24] Nuwayhid A, Makarem M, KhudrA and El-Zein, (2005). The health of children working in small urban industrial shops. Department of environmental health, faculty of Health Sciences, American University of Beirut, Lebanon. http://dx.doi.org/10.1136/oem.2004.015503.

[25] Mitra S, (1993). A study of the health conditions of child workers in a small scale leather industry in Calcutta.

[26] Leske GS and Ripa LW, (1996). Public health and preventive medicine, 14th ed oxford, London, p.p 1142.

[27] Quandt SA, Elmore RC, Arcury TA and Norton D, (2001). Eye symptoms and use of eye protection among seasonal and migrant farm workers. South Medical Journal; 94 (6): 603-7. http://dx.doi.org/10.1097/00007611-200194060-00012.

[28] Assaad R, (2001). The effect of child work on school enrollment in Egypt Minnesota University. Economic research forum for the $\mathrm{Ar}$ ab Countries, Humphrey Institute of Public Affairs.

[29] Hawamdeh H and Spencer N, (2001). Work, family, socioeconomic status and growth among working boys in Jordan. Archives of disease in childhood. 84 (4): 311-14 http://dx.doi.org/10.1136/adc.84.4.311.

[30] Daily star Egypt staff, (2006). Children of the quarries; first published, Daily star, Egypt.

[31] Graitcer P L and Lerer L B, (2000). The impact of child labor on health: report of a field investigation in Egypt. www.Worldbank.org/children.

[32] Human Rights Watch, (2002). Back grounder: child labor in agriculture, children's rights. HRW world report.

[33] Mahmoud A, (1995). Health profile of children working in car repair work shops in Dekernis. Dakahlia Governorate. Master thesis, faculty of Medicine, Mansoura University. 